ARTICLE

\title{
Technical education in the state of São Paulo and public-private relations in curriculum policy: Paula Souza Center (1995-2018)*
}

\author{
Carmen Sylvia Vidigal Moraes' (D) \\ Elydimara Durso dos Reis' \\ Felipe Alencar

\section{ABSTRACT}

This work aims to analyze the relations between public and private in technical education policy-making in the state of São Paulo and, more specifically, concerning the proposals for organizing the curriculum of high school technical education offered by Paula Souza State Center for Technological Education between 1995 and 2018. This study uses primary (government documents and those produced in the institution) and secondary sources (literature review). During this historical period of neoliberal management by the Brazilian Social Democracy Party (Partido da Social Democracia Brasileira) governments in the state, private agents have been observed to play an increasing role in the formulation, monitoring, and evaluation of the institution's curriculum policies. This represents a peculiar process of endogenous privatization of technical education within the state public education system.

\section{KEYWORDS}

technical education; São Paulo state educational policies; curricular proposal; privatization of education.

'Universidade de São Paulo, São Paulo, SP, Brazil.

*This article results from the research Política Educacional na Rede Estadual Paulista (1995 a 2018), funded by the Fundação de Amparo à Pesquisa no Estado de São Paulo (FAPESP), n. 2018/09983-0), and coordinated by Márcia Aparecida Jacomini. 


\section{EDUCAÇÃO PROFISSIONAL PAULISTA E RELAÇÕES PÚBLICO-PRIVADAS NA POLÍTICA CURRICULAR: CENTRO "PAULA SOUZA" (1995-2018)}

RESUMO

O trabalho objetiva analisar as relações entre o público e o privado nas políticas de educação profissional do estado de São Paulo e, mais especificamente, nas propostas de organização curricular do ensino técnico de nível médio desenvolvido no Centro Estadual de Educação Tecnológica Paula Souza, nos anos 1995-2018. O estudo utiliza fontes primárias (documentos governamentais e os produzidos na instituição) e secundárias (revisão bibliográfica). Observa-se, nesse período histórico de gestão neoliberal dos governos do Partido da Social Democracia Brasileira no estado, a crescente atuação de agentes privados na formulação, no monitoramento e na avaliação das políticas curriculares da instituição. Tal movimento caracteriza um processo peculiar de privatização endógena do ensino profissional no âmbito da rede pública estadual de educação.

PALAVRAS-CHAVE

educação profissional; política educacional paulista; proposta curricular; privatização da educação.

\section{EDUCACIÓN PROFESIONAL EN EL ESTADO DE SÃO PAULO Y RELACIONES PÚBLICO-PRIVADAS EN LA POLITICA CURRICULAR: CENTRO PAULA SOUZA (1995-2018)}

\section{RESUMEN}

El trabajo tiene por objetivo analizar las relaciones entre lo público y lo privado en las políticas de educación profesional en el estado de São Paulo y, más específicamente, en las propuestas de organización curricular de la educación técnica secundaria desarrolladas en el Centro Estatal de Educación Tecnológica Paula Souza, entre los años 1995-2018. El estudio utiliza fuentes primarias (documentos gubernamentales y los producidos en la institución) y secundarias (revisión de la literatura). Se observa, en este período histórico de gestión neoliberal de los gobiernos del PSDB (Partido da Social Democracia Brasileira) en el estado, el creciente papel de los agentes privados en la formulación, monitoreo y evaluación de las políticas curriculares de la institución. Este movimiento caracteriza un peculiar proceso de privatización endógena de la formación profesional en la red de enseñanza pública estatal.

\section{PALABRAS CLAVE}

educación profesional; política educativa de São Paulo; propuesta curricular; privatización de la educación. 


\section{INTRODUCTION}

The Paula Souza State Center for Technological Education (Centro Estadual de Educą̧ão Tecnológica "Paula Souza" - CPS1) started its activities in 1969. At the time, it was linked to the Department of Education for administrative reasons and to the Department of Finance for financial reasons, and was intended to offer the first higher technology courses. Over the years, it also offered secondary-level professional education, absorbing existing units of the state education network and building new secondary and higher-level technical schools in all regions of the State of São Paulo (CPS, 2021).

In 1976, CPS was transformed into a special regime autarchy (a condition given only to universities), incorporated into the Universidade Estadual Paulista "Júlio de Mesquita Filho" (UNESP) through Law no. 952/1976 and linked to the Secretariat of Economic Development of the State of São Paulo (Secretaria do Desenvolvimento Econômico do Estado de Sáo Paulo - SDE) to "promote sustainable growth, improving higher, technical, and technological undergraduate education and stimulating innovation [...] with public policies aimed at generating employment and income, and increasing entrepreneurship and the competitiveness of the production sector" (CPS, 2021).

It is currently present ${ }^{2}$ in 369 municipalities and manages 223 State Technical Schools (Escolas Técnicas Estaduais - ETECs) and 74 Technology Colleges (Faculdades de Tecnologia - FATECs), with more than 300,000 students attending technical courses of high and technological undergraduate levels. The ETECs have more than 228,000 students in Technical, High, and High School-Technical Integrated Education, including on-campus, hybrid, and online options, Youth and Adult Education (EJA), and technical specialization, in 212 courses, aimed at all public and private production sectors. FATECs, on the other hand, serve more than 94,000 students enrolled in 86 technological, undergraduate, graduate, technological-updating, and extension courses.

CPS expansion trajectory, according to Sacilotto (2016, p. 25), "follows the historical trajectory of Brazilian professional education" and becomes the "instrument and institutional resource for implementing public policies on professional education and technology in the State of São Paulo."

Despite the reforms introduced in basic education during the period of the civil-military dictatorship (Law no. 5.692/1971), negatively affecting school curriculum and failing to carry out the intended technical training, the schools of the technical education network continued to function without interference, acquiring a differentiated quality, provided in part by the selective access of students through entrance exams and, also, by the relative autonomy of their management. Thus, in the historical specificity of Brazilian society, a duality in inverted education is manifested: the regular public school, propaedeutic, is the modality of greater access by

1 There are two acronyms used by the institution: CPS and CEETEPS.

2 CPS. About the Centro Paula Souza. Available at: https://www.cps.sp.gov.br/sobre-o-centro-paula-souza/. Accessed on: 11 dez. 2021. 
the poor population, while the secondary public technical school becomes selective, destined to a smaller number of people (Moraes, 2006; 2017).

Since the enactment of the National Education Guidelines and Framework Law No. 9.394/1996 (Lei de Diretrizes e Bases da Educação Nacional — LDB/1996), the high school format and its attributions became a source of dispute. Soon after the approval of LDB, Fernando Henrique Cardoso (FHC) government issues Decree 2.208/1997, which separated secondary and technical education and unschooled technical education, to dismantle the highly costly professional secondary education offered in federal and state technical schools. International Bank for Reconstruction and Development (IBRD) and The International Monetary Fund (IMF) proposals were carried out by the state and federal governments. A successful conceptual and pedagogical reformulation takes place - from the name professional teaching, which becomes professional education, to the shift from the notion of qualification to the notion of competence, with its serious implications in curriculum proposals and, therefore, in the relationship with knowledge. At the same time, measures were introduced to reorganize education networks in their physical and administrative aspects, standardizing important means and processes such as textbooks, centralized curriculum proposals, and external evaluations, measures understood as necessary for economic growth, modernization of the country, and its inclusion in the list of the most developed capitalist economies (Souza, 2013). In addition to not having caused changes in the precariousness of the services provided in schools, the reforms implied a lack of character and greater disqualification of secondary education.

Within the framework of neoliberal policies, the State Reform, the so-called New Public Administration (Laval, 2004; Verger and Normand, 2015), and the political and philosophical assumptions that inform the educational policies of PSDB governments since 1995 in the State of São Paulo, it is relevant to research the educational policy of the state of São Paulo in a broad historical period, involving different dimensions of the actions carried out by the Secretariat of Education (Secretaria de Educação - SEE) ${ }^{3}$ and by the Secretariat of Economic Development, Science, Technology, and Innovation of the State of São Paulo (Secretaria de Desenvolvimento Econômico, Ciência, Tecnologia e Inovação do Estado de São Paulo), to which CPS is linked, to examine policy-making aimed at secondary level technical professional education and continuing education, in its relationship with the regulations and guidelines of the federal government in the defined period.

In light of the policy cycle approach, the contexts of influence and production of the text and practice are considered (Ball, Maguire and Braun,2016). In this sense, some reflections are outlined herein for the analysis of the process of formation of public-private relations in the administrative and pedagogical organization of CPS, between 1995 and 2018. Initially, a brief history of the expansion of professional education in the state of São Paulo is developed, with an emphasis on the main legal changes and their impact on policy, and then, curriculum policy is examined,

3 Cf. SE Resolution no. 18, of May 2, 2019, the acronym of the Secretariat of Education - SEE-SP - was changed to SEDUC-SP. 
focusing on the curricular matrices of the administration program, understood as a means of materializing the intervention of private agents in professional education (Moraes and Alencar, 2020).

To better understand the "huge web of actors and situations that interact in the trajectory of educational policies"(Ball,1989,p.24), it is important to contextualize them in the set of changes that invade the national and international scenarios, highlighting some important moments in the institutional configuration of CPS concerning its relationship with federal policies for the organization of professional education.

In the fieldwork, concerning primary sources, a survey was carried out on national and state educational legislation, social and educational indicators, and institutional documents: educational proposals and projects produced and implemented in CPS and its network of schools, those elaborated by the Secretariats and the government of the State. As for secondary sources - location and review of the bibliography related to professional education in the state network and, specifically, to CPS - it is important to note the scarce number of studies and research found on the origins and development of the institution and its professional schools ${ }^{4}$. Only four academic papers were found, a monograph (published in 2017), a doctoral thesis (published in 2016), produced in the Graduate Program in Education at the School of Education, Universidade Estadual de Campinas (FE-UNICAMP), and two professional master's degrees defended, in 2020, at FATEC-CPS. Such works, referenced in extensive document consultation, constituted important references in the elaboration of our text.

\section{PROFESSIONAL EDUCATION IN THE STATE OF SÃO PAULO: BETWEEN CONTAINMENT AND EXPANSION}

From the inauguration of Mário Covas, in 1995, to the departure of Geraldo Alckmin, in 2018, for the presidential race, only PSDB was ahead of the government of São Paulo. After Covas (who died in 2001), Geraldo Alckmin/Cláudio Lembo (2001-2006) and José Serra (2007-2010) alternated. This was a great expansion period for CPS.

After an initial moment of discussion and the Covas government clearly stating it intended to reorganize the institution, "stop the creation of new courses and units," and review agreements and "labor relationships" ${ }^{5}$, facing resistance from movements organized by professors, employees, and students throughout the period, PSDB's subsequent managements will change their position, expanding the network by increasing the number of schools - ETECs and FATECs throughout the state.

4 The survey was carried out in the Catalog of Theses and Dissertations/Coordination for the Improvement of Higher Education Personnel (Coordenação de Aperfeiçoamento de Pessoal de Nivel Superior - CAPES) according to the following selected terms: Centro Paula Souza, educational policy, and professional education in the state of São Paulo.

5 CPS workers had no wage increase for eight years. Reports from managers at the time signal the unhappy atmosphere in the institution. A career plan was only created in 2008, when employees were also hired and wages increased (Complementary Law no. 1.044/2008). See Fiala (2016). 
Between 1997 and 2002, CPS sought to improve the infrastructure of the schools without promoting any expansion. The year 2002 marks the introduction of professional education in the public policy agenda of the state government (Sacilotto, 2016) and, unlike previous expansions, which incorporated existing schools and the creation of few units, the expansion via the creation of new schools will characterize the administrations of PSDB.

In the 1990s, in the new configuration imposed on the Brazilian State, changes in nature in its public dimension tend, as Cohn (2004) assesses, to transplant the rationality of the private sector into its interior, replacing republican criteria of social management with private-oriented criteria, guided by the rationality of cost-effectiveness, which ignores the dimension of social rights.

Until the validity of Federal Decree no. 2.208/1997, professional technical education was offered simultaneously and in an integrated manner with general secondary education, in federal and state networks of technical schools to provide professional training in the areas of service, industry, and agriculture. To comply with the provisions of the LDB/1996 and the Federal Decree, the government of the State of São Paulo promoted changes in state schools, blocking enrollment in the initial grades of vocational courses, while determining the separation between secondary and technical education.

The changes in the administrative, pedagogical, and didactic-curricular organization introduced in CPS technical schools, resulting from the implementation of Federal Decree 2.208/1997, are associated with the interference of international and national organizations, the interests of the social sectors of Brazilian society, the adoption of a neoliberal agenda by the FHC government, and the very dynamics of the institution that supports state technical schools and the social subjects that interact with it, which can be summarized as follows: disengagement of technical education from secondary education; modularization of courses; reformulation of curricula according to the competence model, reformulation of conventional models of knowledge acquisition, and systematization of teaching quality assessment mechanisms (Koritiake, 2008; Sacilotto, 2016).

According to the Ministry of Education (MEC), in the document Strategic Planning 95/98, in the case of professional courses, "the axis of articulations will turn to professional training institutions (National Service for Industrial Apprenticeship - Serviço Nacional de Aprendizagem Industrial - SENAI; National Commercial Learning Service - Serviço Nacional de Aprendizagem Comercial-SENAC; National Rural Apprenticeship Service - Serviço Nacional de Aprendizagem Rural-SENAR; National Transport Apprenticeship Service - Serviço Nacional de Aprendizagem do Transporte - SENAT, and similar) and to the production sector itself" (Moraes, 2001). In this sense, integrating the neoliberal governmental agenda and based on the premises of the Theory of Human Capital, the decree governing the reform of technical education provides, like in the National System of Industrial Learning (Senai), that schools include the participation of local businessmen in the board of directors (Board of Directors and Advisory Council) so that they can guide the schools according to the demands of local businesses. And, like SENAI, it proposes to adjust schools to the market by organizing teaching curricula, having 
as a parameter the occupational profile and demands (competences) of the labor market - and no longer "curricula assembled from academic subjects" (Oliveira, 1995), in the expression of an IBRD consultant.

As one of the reform's objectives, Decree 2.208/1997 states that it is necessary to follow technological advances to meet the new demands of the market, which requires "flexibility, quality, and productivity". When formulating the proposal, aimed at the continuous development of skills for a productive life, the technical education curriculum is structured by areas and sectors of the economy and organized, preferably, in a modular form. The modules can be taken at different institutions and have a terminal character for professional qualification and certificates of competence. Attendance and approval in all modules referring to a technical qualification or passing exams organized by the federal and state education systems grant the student a certificate of secondary technical school completion in that qualification.

In this sense, the MEC document, which establishes the national curriculum parameters for professional education (minimum content, basic skills, and competences), considers that "the organization in modules should provide greater flexibility to professional training institutions [...] as courses, programs, and curricula may be periodically restructured and renewed, according to the emerging and changing demands of the world of work" (Brasil, 1999, p. 18).

The digression on federal policies, developed as part of PSDB's educational program coordinated by Paulo Renato Souza, Minister of Education during both terms of FHC (1995-2002), aims to indicate their consonance with the policies developed in the State of São Paulo and, in particular, in CPS, both concerning measures aimed at curbing the expansion of the network, as well as the pedagogical concepts that guided curricular policies and evaluation processes in the institution.

Considering federal legislation and process no. 119/97, of the São Paulo State Council of Education, in the case of CPS, the planned changes were carried out: secondary education is parallelly maintained in state schools, with separate enrollments and operating in the morning shift, reserving the afternoon and night shifts for professional education, the latter preferably aimed at students who have already completed high school and who work during the day. The measure aimed to give greater functionality to the network, rationalizing its resources and, at the same time, adapting it to federal legislation and state regulations. Technical education started to have its own curriculum, organized in a modular form, based on the model of competences, with minimum class hours provided for in the legislation (Brasil, 1997) 6 .

In 2000, CPS drafted the document Professional Education in São Paulo to affirm its institutional project of offering courses, sent to state congressmen of the São Paulo Legislative Assembly (Assembleia Legislativa de São Paulo - ALESP), to support communication about the changes in professional and technological education and in the State, and outlining "the new model of professional education". The proposal of "pedagogical and institutional adaptation of CPS to the type

6 The courses started to have a six-month term and duration of 1,500 class hours, with 400 hours of internship, totaling 1,900 class hours (Moares e Ferretti, 1999, p. 237). 
of management required by the new model" was aligned with the perspective of "inserting or reinserting citizens in the world of work and integrating the economy of São Paulo to the ever-changing market of a globalized world" (CPS, 2000).

The victory of the Workers' Party (Partido dos Trabalhadores - PT) government and the changes in secondary education and professional education policies in the country (Federal Decree 5.154/2004) brought a new dilemma for the CPS Central Administration: to maintain regular secondary education at the Etecs or to integrate it with technical education.

Documents from CPS, the CPS Workers Union (Sindicato dos Trabalhadores do CPS - SINTEEPS), and surveys by Sacilotto (2016) and Santana (2016) point to problems for the effective implementation of the integrated form of high school with technical professional education at CPS: reduction in the number of vacancies and students; increase in the cost per student due to the end of regular high school part-time shift; the need for significant changes in the curriculum of the courses to overcome segmentation and disarticulation between subjects; teachers and administrators are not familiarized with the concept of integration; and lack of adequate conditions for student learning. In addition to these difficulties, changes were made to the design and guiding principles of curriculum, defined in the Curriculum Guidelines for Technical Professional Education at Secondary Level (Resolution CNE/CEB 6/2012 and Opinion CNE/CEB no. 11/2012).

Thus, although Federal Decree 5.154/2004 resumed the possibility of offering technical education integrated to secondary education as of the 2005 school year, the first experience of integrated education is only resumed in 2010, with the professional qualification of Mechatronics integrated to high school. After 2005, the forms of offering courses remain identical to those previously available, that is, technical education concomitantly with and subsequently from ${ }^{7}$ and high school, separately, with different enrollments ${ }^{8}$.

The administrative and pedagogical restructuring was accompanied by the expansion of the service capacity of the existing teaching units to increase available places, including the provision of secondary education in ETECs that was not available. The creation of new units began during the Alckmin/Lembo government (2001-2007) and was intensified during the Serra government (2007-2010): from 138 ETECs and 33 FATECs, with 123,000 students and 11,000 workers, in 2007, the institution was upgraded to 198 ETECs and 49 FATECs, with 196,000 students and 16,000 workers in 2010 (Quintino, 2020, p. 92).

According to a 2002 report by the Secretariat of Finance and Planning of the State of São Paulo (Secretaria da Fazenda e Planejamento do Estado de São Paulo -

7 They are intended for those who attend high school and those who have already completed it, respectively.

8 The state of São Paulo instituted High School Integrated Technical Education with a Federal Program entitled Professionalized Brazil (Brasil Profissionalizado) in 2007. This provided funds for the states that wanted to strengthen their technological professional education networks, as a goal of the Education Development Plan (Plano de Desenvolvimento da Educação - PDE). In 2014, CPS made it available in 175 units (Lima, 2020, p. 102). 
SFP-SP), the resources of the Federal Program for the Expansion of Professional Education (Programa Federal de Expansão da Educação Profissional - PROEP), made possible through an agreement between MEC and the Inter-American Development Bank (IDB), financed the development of school projects in the socalled Technical Schools (Escolas Técnicas - ETE) of São Paulo, Santos, Botucatu, Ribeirão Preto, and São José do Rio Preto (Quintino, 2020, p. 91).

Sacilotto (2016) and Fiala (2017) show that, unlike other state educational institutions, such as the three public universities - Universidade de São Paulo (USP), UNICAMP and UNESP -, which are special regime autarchies integrated to the same state secretariat, CPS has never had financial autonomy, nor has its budget been legally linked to percentages of state revenues. The budgetary decoupling and the lack of autonomy lead to random changes in the financing of the school network, in its different management, didactic-pedagogical activities and, in this case, in the expansion of the offer and teaching quality.

Technical schools reacted to fluctuations and budget constraints (and sometimes the CPS management itself, directly or by induction) by resorting to alternative forms of financing, which Sacilotto (2016) characterizes as "foundational pacts of public policy": projects financed by foundations and development agencies; resources from School Cooperatives (in "agricultural" schools); a share of the amount paid by applicants when registering to the entrance exam; contributions of students to the Parent-Teacher Associations of the schools, among others. In addition, this research study lists several projects, developed at ETECs and FATECs, financed by private law foundations, such as Fundação Vitae and Technology Support Foundation (Fundação de Apoio à Tecnologia - FAT) ${ }^{10}$. The Technical Education Support Program was created in 1996 by Fundação Vitae - Support for Culture, Education, and Social Promotion, to contribute to the improvement of secondary-level technical professional education in Brazil.

In 2006, after Vitae resumed its activities, FAT took over the management of the Program in partnership with other institutions, including Fundação Lemann (since 2002), Instituto Unibanco, Banco Itaú BBA, and Fundação Itaú Social, as of 2007 (Fundação FAT, 2009, p. 13 apud Sacilotto, 2016). It is now called "Partners-Vitae to Support Technical and Agri-technical Education," with the same objectives and forms of financing. In the period between 1996 and 2013, 96 CPS ETEC projects were financed, which included updating and building laboratories in different courses (Fundação FAT, 2009, p. 13-14 apud Sacilotto, 2016).

According to the 2004-2008 Management Report (CPS, 2009), in this period, 373 agreements were signed, of which 97 were for the creation of decentralized classes ${ }^{11}$. The municipal governments "stand out among the partners who

9 About Fundação Vitae, see Almeida and Herência (2012).

10 FAT is a private law foundation, created by Fatec professors in São Paulo, in 1987, which organized and carried out entrance exams and admission processes at Fatecs and Etecs. See: fundacaofat.org.br/fundacao/. Accessed on: July 10, 2020.

11 Format authorized by the State Council of Education of São Paulo, in 1999, as a means of expanding CPS offer using other institutional spaces, which characterizes a trend towards the precariousness of teaching conditions, see Quintino (2020). 
entered into agreements with the institution, both for the Decentralized Classes and for the implementation of new Etecs and Fatecs" and also partnerships with the private sector: "several agreements entered into with sugar and alcohol plants, industries, and companies for training and qualification courses for their employees, mostly in Decentralized Classes", highlighting the "fundamental role of Fundação FAT in the implementation of highly relevant agreements" (CPS, 2009, p. 22-23; CPS, 2016, p. 6 apud Sacilotto, 2016).

\section{PRIVATIZATION IN PROFESSIONAL EDUCATION}

According to information from the director of the Curriculum Analysis Formulation Group (Grupo de Formulação de Análises Curriculares - GFAC) of CPS, Fernanda Demai (2019, p. 34), over the last 20 years, the institution, through the Secondary and Technical Education Unit (Unidade do Ensino Médio e Técnico - CETEC), has been carrying out activities associated with the elaboration and re-elaboration of the curriculum through the "Curriculum Laboratory" "along with public and private specialists and institutions, prioritizing the establishment of partnerships".

In 2000, with the publication of the National Curriculum References for Professional Education at Technical Level, by MEC, the objective was breaking with the paradigm of the Technical Professional Education Curriculum (educação profissional técnica - EPT) focused on the "content to be taught" to advocate for the new "paradigm under implementation," focused on the skills to be developed and knowledge to be built - "knowing, knowing how to be, and knowing how to do." In this sense, according to the references, the curriculum "is no longer an end to be achieved, a simple list of contents taught and learned" (Demai, 2019, p. 24). It is now "a set of situations considered to be the means, pedagogically conceived and organized to promote meaningful professional learning" (Brasil, 2000, p. 11).

For nearly a decade, the organization of the high school EPT was guided by the triad - "competences," "skills", and "technological bases" - , and built from categories called "professional areas," following parameters of multilateral organizations, especially the World Bank/IBRD, and "conceptual changes" introduced by the European Community White Paper, in 1995. In Lula's government, new Decree no. 5.154/2004 is enacted, replacing the previous one and reintegrating technical professional education into secondary education. However, the paradigm of high school EPT was remodeled only in 2008 with Resolution CNE/ CEB No. 3, of July 9, 2008, and MEC's National Catalog of Technical Courses (Catálogo Nacional dos Cursos Técnicos - CNCT), replacing "professional areas" with "technological axes," so that the competence model would be overcome by the conception of polytechnics or "common polytechnic nucleus for each technological axis" (Machado, 2010, p. 93).

In the critical evaluation of CPS, both the 2000 Curriculum References and the 2008 CNCT lack "sufficient information for curriculum standardization". For this reason, CPS would use, for technical courses, "a hybrid methodology of studies and curriculum formulations, seeking, in addition to [...] legal refer- 
ences, research with the production sector, other institutions that offer EPT and other government agencies, such as the Ministry of Labor and Employment" (Demai, 2019, p. 29). With these concerns, work meetings and editions of the Professional Education Forum had been organized in 2006, involving the main institutions that develop technical and technological training in the state of São Paulo: CPS, the Federal Institute of Education, Science, and Technology (Instituto Federal de Educação, Ciência e Tecnologia - IFSP), SENAI São Paulo, National Association of Technological Education (Associação Nacional de Educação Tecnológica), National Commercial Learning Service (Serviço Nacional de Aprendizagem Comercial), Regional Council of Chemistry 4th Region (Conselho Regional de Química $4^{a}$ Região), High School Industrial Technicians Union of the State of São Paulo (Sindicato dos Técnicos Industriais de Nivel Médio do Estado de São Paulo), and Union of Technologists of the State of São Paulo (Sindicato dos Tecnólogos do Estado de São Paulo).

As of 2008, two annual editions are held "based on an initiative by the aforementioned institutions," in which topics of relevance to the EPT are addressed and diagnoses of its situation in the state of São Paulo and the country are prepared, with an emphasis on curriculum planning - concepts and practices in the development of curriculum designs for their training itineraries and course plans. The events have, on average, 200 participants, including teachers and educational managers, and are hosted by the institutions that make up the Forum (Demai, 2019, p. 81-82).

In 2012, the Technical Secondary Education Network Program Vence (Rede de Ensino Médio Técnico Vence) is implemented through Decree no. 57.121/2011, with changes introduced by Decree 58.185/2012 and SE Resolution 78/2012. The provision of secondary education included curricular components from the Common National Core, a diversified part, and secondary-level professional training, developed by state public schools in an inter-complementary regime with units of CPS and IFSP. Recently, with the secondary education reform, Federal Law No. $13.145 / 2017$, considerable changes were implemented in this stage of education as indicated below.

The historical elements of the organization of high school technical education at CPS indicate that curriculum development and re-elaboration occurred in accordance with the federal legislation, with adjustments provided by the injunctions of the São Paulo State Government and by the institution's relative autonomy in its pedagogical organization, in addition to administrative and financial organization (Moraes and Alencar, 2020).

\section{PRIVATE AGENTS IN CURRICULUM POLICIES}

The curricular conformation processes in EPT took place through the priority development of partnerships with the "production sector," totaling, between the years 2000 and 2018,112 partners, who increased from 4 in 2000 to 37 in 2017 and to 70 in 2018. Out of this total number of institutions, there were 31 partnerships with state or non-profit authorities and 81 partnerships with the private sector. This 
shows a growing approximation between schools and the market in the period. By private we mean being associated with the market and neoconservatism, and that has implications for the democratization of education (Peroni, 2015).

Chart 1 below lists public sector institutions and Chart 2 lists four private sector partners that have been selected for the extent of their interference in CPS technical courses:

\section{Chart 1 - Partnerships with the public or non-profit sector in Technological Education (2000-2018).}

\begin{tabular}{|c|c|}
\hline São Paulo City Council & $\begin{array}{c}\text { Universidade de São Paulo } \\
\text { Geosciences Institute } \\
\text { (Instituto de Geociências da } \\
\text { Universidade de São Paulo) }\end{array}$ \\
\hline Ourinhos Cultural Center & Ministry of Labor \\
\hline $\begin{array}{c}\text { Center for Studies and Research } \\
\text { of Municipal Administration }\end{array}$ & Landless Rural Workers' Movement of \\
\hline $\begin{array}{c}\text { Reference Center for Alcohol, } \\
\text { Tobacco, and Other Drugs }\end{array}$ & Jundiaí City Hall \\
\hline $\begin{array}{c}\text { Municipal Commission for the } \\
\text { Prevention of Avian Diseases }\end{array}$ & Ourinhos City Hall \\
\hline Traffic Engineering Company & São Paulo Transport \\
\hline $\begin{array}{c}\text { Basic Sanitation Company of the } \\
\text { State of São Paulo SA }\end{array}$ & Department of Culture \\
\hline São Paulo Metropolitan Company & Department of Energy and Mining \\
\hline $\begin{array}{c}\text { São Paulo Metropolitan Train Company) } \\
\text { Sutantan Institute, Botany Institute/Secretary of } \\
\text { the Environment of the State of São Paulo }\end{array}$ & $\begin{array}{c}\text { Department of Housing and Land Regularization } \\
\text { Institute of Santo André City Hall }\end{array}$ \\
\hline State Council of Narcotics & São Paulo State Department of Health \\
\hline $\begin{array}{c}\text { Farmers' Cooperative of the Region of Orlândia } \\
\text { Dr. Carlos de Campos/Tatuí }\end{array}$ & Union of Secondary Level Technicians of the \\
State of São Paulo
\end{tabular}

Câmara Municipal de São Paulo; Centro Cultural de Ourinhos; Centro de Estudos e Pesquisas de Administração Municipal; Centro de Referência de Álcool, Tabaco e Outras Drogas; Comissão Municipal de Prevenção de Doenças Aviárias; Companhia de Engenharia de Tráfego; Companhia de Saneamento Básico do Estado de São Paulo SA; Companbia do Metropolitano de São Paulo; Companhia Paulista de Trens Metropolitanos; Conselho Estadual de Entorpecentes; Conselho Regional de Administracão/São Paulo; Conservatório Dramático e Musical Dr. Carlos de Campos/Tatuí; Cooperativa de Agricultores da Região de Orlândia; Departamento de Estradas e Rodagens; Hospital Geral de Taipas; Instituto Butantan, Instituto de Botânica/Secretaria do Meio Ambiente do Estado de São Paulo; Instituto de Geociências da Universidade de São Paulo; Ministério do Trabalho; Movimento dos Trabalhadores Rurais Sem Terra; Prefeitura Municipal de Jundiai; Prefeitura Municipal de Ourinhos; São Paulo Transporte; Secretaria da Cultura; Secretaria de Energia e Mineração; Secretaria de Habitação e Regularização Fundiária/Prefeitura de Santo André; Secretaria do Estado de Saúde de São Paulo; Sindicato dos Técnicos de Nivel Médio do Estado de São Paulo; Tribunal de Justiça de São Paulo.

Source: Prepared by the authors based on Demai (2019, p. 93-101) 
Chart 2 - Private agents and technical courses under their intervention in Technological Education (2000-2018).

\begin{tabular}{|l|c|c|}
\hline Institution & Course & Year \\
\hline \multirow{5}{*}{ IBM Brasil } & Java/WR Specialization & 2008,2013 \\
\cline { 2 - 3 } & Specialization in Mainframe Development and Production & 2013 \\
\cline { 2 - 3 } & $\begin{array}{c}\text { Technician in Systems Development Integrated to High } \\
\text { School; Technician in Computing Integrated to High School; } \\
\text { Computer Technician for the Internet Integrated to High } \\
\text { School; Maintenance and Support Technician in Computing } \\
\text { Integrated to High School; Computer Network Technician; } \\
\text { Telecommunications Technician }\end{array}$ & 2017 \\
\cline { 2 - 4 } Google & $\begin{array}{c}\text { High School with Professional Qualification as a Database } \\
\text { Administrator (MTec) }\end{array}$ & 2018 \\
\hline Microsoft & $\begin{array}{c}\text { Technician in Systems Development Integrated to High } \\
\text { School; Technician in Computing Integrated to High School; } \\
\text { Computer Technician for the Internet Integrated to High } \\
\text { School; Maintenance and Support Technician in Computing } \\
\text { Integrated to High School; Computer Network Technician; } \\
\text { Telecommunications Technician }\end{array}$ & 2017 \\
\hline Rede Globo/ \\
FundaçãoRoberto \\
Marinho & $\begin{array}{c}\text { Technician in Business Administration - Distance Learning } \\
\text { Mode; Small Business Management Technician - Distance } \\
\text { Learning Mode; Secretarial and Advisory Technician - } \\
\text { Distance Learning Mode; }\end{array}$ & 2005 \\
\cline { 2 - 4 } & $\begin{array}{c}\text { Multimedia Technician; Audio and } \\
\text { Video Production Technician }\end{array}$ & 2011 \\
\hline
\end{tabular}

Source: Prepared by the authors based on Demai (2019, p. 93-101).

As indicated in Chart 2, the private agents involved in defining the curricular structure of CPS courses are large corporations with high equity, which have been operating in the institution since 2005. Google and Microsoft intervene in the same courses since 2017, Rede Globo/Fundação Roberto Marinho, since 2005, and it was the broadcaster that detected "the need for training that would mobilize technical skills to work in audiovisual and multimedia language within its own reality and asked CPS to organize this work" (Guerra, 2019, p. 294), a partnership that also resulted in the construction of ETEC Roberto Marinho. Finally, IBM Brasil intervenes in CPS since 2008, in 10 courses, offering the P-Tech program in the United States, Morocco, and Australia, aimed at the information and communication technological axis. At CPS, students have internship experiences with partner companies and obtain the corresponding high school-level and higher-level technician diploma in technology.

Under the guidance of the Curriculum Laboratory, "partners in the production sector must be included in the catalog card mentioning the credits for the course plans, and [...] sign a technical opinion report approving the curriculum planning documents (course plan)" (Araújo and Demai, 2019, p. 92). This shows 
the incidence of these partnerships with the production sector in defining what should be prioritized in the curriculum.

According to Araújo (2019, p. 251), the general coordinator of secondary and technical education at CPS, in every curriculum designed over the last 20 years,

CETEC has mediated the process, managing the Curriculum Laboratories (process, products, and teams set up by specialists from companies and Etecs) concerning the (re)development of the curriculum, with definitions about attributions, professional competences, facilities, theoretical and practical workloads being agreed upon by the collective. [...] The description of the professional profile is detailed in the attributions and activities, having as a limit the analysis of what is foreseen for the functions/positions of the consulted companies and those of the same family described in the Brazilian Classification of Occupations (CBO) of the Ministry of Work and Employment.

The coordinator clearly describes the construction of curricular contents guided by the professional performance demanded by companies in the different production sectors and occupational families defined in $\mathrm{CBO}$, according to the competency model. It also objectively explains the institutional appropriation of the notion of competence, understood as operational knowledge aimed at the practical resolution of problems in work situations, in accordance with the formulations of companies and their foundations, and with the major guidelines in the governmental field.

The functions that structure the stages of work (planning, execution, and control) help to define the curricular components: subjects, projects, and activities, that is, the functions that are a reference for organizing the work are, consequently, the basis for designing the curriculum of technical and technological courses. They also, in some courses, delimit modules and certifications. During the training of technicians, the experiences developed inside and outside an ETEC play an important role in the construction of competences provided for in the curriculum, because we work with the definition of professional competence. (Araújo, 2019, p. 251)

Although the Curriculum Laboratory document does not ignore the social condition and inequality of students, a distinction is given to training based on competences, seen as training inducing behaviors (socially and emotionally) adapted to the market norms and, therefore, promoting the capacity to work and employability under marginalist economic theories:

[...] professional skills mobilize ethical and behavioral values and attitudes, which lead the technical professional to be adapted to different professional and life situations. This is also a condition to take over and be kept in a function, career, position, or other forms of work, such as self-employment or remote work, among others. (Demai, 2019, p. 32) 
The director of CPS GFAC informs that 3 to 5 new curricula are prepared annually, in a public-private partnership, and approximately 25 to 30 curricula are systematically re-elaborated per year (Demai, 2019, p. 36). This shows permanent changes in the training courses for students in line with the demands presented by the market. According to Laura Laganá, Head of CPS:

One of the elements that stand out in the work of the CPS Curriculum Laboratory is the development of courses in partnership with the production sector, offering training that is strategically focused on regional demand. The best way to train well-prepared professionals is to listen to what companies have to say about their needs - this helps to maintain the high level of employability of ETEC and FATEC students. (Laganá, 2019, p. 11)

With this logic in mind, in 2011, Paula Souza Innovation Agency (Agência Inova Paula Souza) was organized to ensure the necessary symbiosis between courses and knowledge production for technological innovation in private sector companies. According to the 2008-2012 management report:

In order to intensify Paula Souza's proximity to the private sector, with regard to contributing to the innovation of companies, Inova participated in several events and technological fairs to disseminate studies and opportunities for the transfer of knowledge and technologies developed by the students of the institution. (CPS, 2012, p. 54-55)

An element that formally explains this permanent approximation is the inclusion of entrepreneurship, as of 2014, as a transversal competence or explicit in the form of a curricular component in all courses and technological axes in CPS. The alignment of behavioral, pragmatic, and planning focus once again updates the lexicon of the corporate world: problem-solving with management and creativity tools, objective communication, initiative, strategic and systemic vision oriented to the goals of the production sector, measurement of impact, economic sustainability (Demai, 2019, p. 69-70).

In the management report of the following period, 2012-2016, the perspective of entrepreneurship in technical education was characterized as positive from an institutional point of view:

A recent focus on innovation and entrepreneurship, present in the initiatives of Paula Souza Innovation Agency, as well as in course curricula, teaching methodology, and teacher training, aligns training at all levels with the most current demands of the economy. (CPS, 2016, p. 14)

With the implementation of Vence in 2012, there is an equivalence to Technical Education Integrated with High School (Programa em equivalência ao Ensino Técnico Integrado ao Médio - ETIM) in case high school takes place at a SEE-SP school and Technical Education at CPS ETEC or when High School and Technical Education take place at a SEE-SP school being certified by CPS (Maia, 2020). 
Finally, in 2018, based on the provisions of Federal Law no. 13.415/2017, which reformulated High School, CPS implemented a new high school model, with the provision of training itineraries consisting of curricular components of the Common National Core (Base Nacional Comum Curricular - BNCC) combined with a diversified part. The "thematic matrices" are being defined by GFAC, under implementation since 2018, even before the approval of the BNCC in the state $(12 / 14 / 2018)^{12}$.

According to the CPS pedagogical coordinator, "the criticisms of the secondary education reform are not consistent with the reality of the new CPS proposals for basic education". For him, "flexibility benefits a weakened national model":

It can be arrogant or idealistic to think that a unitary high school serves everyone. In the state of Acre, in the backlands of Bahia, and in São Paulo, it is not possible for everyone to have the same education. The idea is that training is contextualized with the region, the young students, and their families. (Araújo, 2019)

As already indicated, CPS frequently points out that the "production sector" is the curriculum designer, giving it a pragmatic sense of meeting the demands of private agents by adapting the curriculum to the skills required by the market. Therefore, it is worth asking: when and how can the individuals involved with the school express their opinions?

In the document produced by CPS Curriculum Laboratory, the school curriculum is "a product of human manifestation, formatted with the objective interests of one or more groups" (Demai, 2019, p. 43). For the general coordinator of secondary and technical education,

The curricula built over the last 20 years are the result of a consensus between the applicants' intentions and what CETEC specialists and Etecs teachers consider to be pertinent in light of the experiences and reflections on professional training in high school. (Araújo, 2019, p. 251)

Despite the intentions of the discourse, it is important to point out that CPS institutional document School Observatory (Observatório Escolar) explicitly outlines a school administration model that suggests a mosaic of different classifications of the term management: pedagogical, facility, participatory, people, document, partnership, support services management (Ramos, 2011,p. 32). All of these dimensions are evaluated by a performance index, formulated by CPS board and coordination, and executed by the School Council through the application of a self-assessment instrument (Ramos, 2011, p. 63).

12 In this regard, see Piolli and Sala (2019). The next section of this article will outline the changes that drastically reduced the contents in the curriculum of courses, arising from these reformulations in educational policy. 
These different classifications for "management practices" seek to replace the principle of democratic management of public education, enshrined in CF/1988. In CPS, a management model is adopted from the business administration, whose approach follows the systematic Plan-Execute-Verify-Act (Plan, Do, Check, Act - PDCA - Cycle) of regular managerial organizations.

The framework of "partners" from the private sector, which shapes the format of the courses according to their demands, and the management perspective of CPS, provided for in the School Observatory, are strong evidence that the institutional functioning does not provide for democratic spaces in which the school community can participate with the right to voice their opinions and the possibility of decision about the direction of the educational process. On the other hand, private agents have a privileged place in the formulation, implementation, and evaluation of the execution of their demands materialized in the CPS curricular policies.

Starting from the concept of curriculum as a selection of knowledge considered necessary in a given historical time, circumscribed from a social, cultural, and political point of view, it can be said that the participation of the private sector is, therefore, decisive in determining the curriculum of the courses at the Paula Souza Center.

\section{CURRICULUM MATRICES FOR THE PROFESSIONAL QUALIFICATION OF ADMINISTRATIVE TECHNICIANS ${ }^{13}$}

In the database provided by CETEC ${ }^{14}$ for the first semesters of 1998 and 2008 (year in which the offer of technical education integrated to high school would have returned "with full force" according to CPS 2008-2012 management report, p. 26), and 2020, it appears that the perspective of integrated education is beginning to recover but is still below the rates observed in 1998 .

Based on the graph below, it is assumed that the integrated format was virtually extinct around the year 2008 when its representativeness was close to $1 \%$, when compared to other teaching formats.

The Graph 1 shows an increase in the number of general vacancies for the period, which increased from 77,685 in 1998 to 118,217 in 2008. In 2020,224,515 students are enrolled in Technical Education, Integrated High School, and High School. Such increase accompanied by the return of integrated high school courses that have included, since 2018, in most technical schools, "High School with the $5^{\text {th }}$ Training Itinerary (Technical and Professional Training) - MTec, [...]. In 2020, this curricular proposal was incorporated into the NOVOTEC Program of the Secretariat of Economic Development" (Maia, 2020, p. 316).

13 Namely: Professional Qualification as a Technician in Administration; Technician in Administration Integrated to High School (ETIM); and High School with Professional Qualification as a Technician in Administration (NOVOTEC). All curricular matrices outlined herein were extracted from their respective course plans.

14 Mapping of the total number of students. Available at: cpscetec.com.br/. Accessed on: July 12, 2020. 


\section{Distribution of enrollments by type of education}

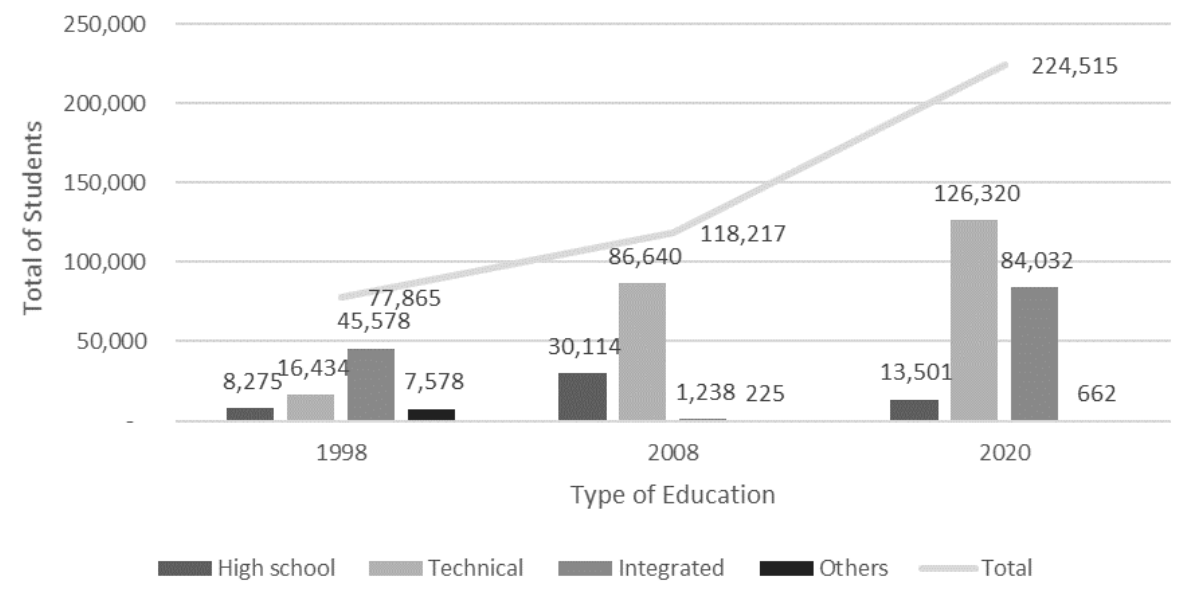

The category "Other" in the Graph corresponds to the professional education courses for Initial and Continuing Training (Formaçẫo Inicial e Continuada - FIC) in 1998; EJA courses (not integrated with technical courses), FIC, and specialization in 2008; and specialization courses in 2020.

Source: Prepared by the authors based on the CETEC database, July 12, 2020.

Graph 1 - Distribution of enrollments by type of education.

The Management and Business axis, according to data from CETEC, has the largest number of enrollments in the first half of 2020 (89,249 students, $\left.39.8 \%{ }^{15}\right)$ followed by the Information and Communication axis $(31,696 \mathrm{stu}-$ dents, 14.1\%), and the Control and Industrial Processes axis (27,771 students, 12.4\%).

Among the courses offered by CPS, the administration course is analyzed as it is one of those that make up the Management and Business axis and gathers the largest number of students in technician courses in 2020. According to the latest consolidated data released in the CETEC database, out of a total of 224,515 students enrolled, including high school only, the administration course accounted for 50,391 ${ }^{16}$ enrollments (22.4\%), considering on-site and distance learning technical courses, and concomitant, subsequent, and integrated courses.

The curriculum of the Administration course in High School Technical Professional Education between 2000 and 2018 includes the following partnerships (Chart 3).

15 The percentage values presented here are approximate values and take into account the total number of enrollments per year.

16 High School with Professional Qualification as an Administrative Assistant, Finance Assistant and Marketing and Sales Assistant - MQTec (NOVOTEC) was excluded because this is not a technically qualified course like the others. 
Chart 3 - Partners in the formulation of administration courses (2005-2018).

\begin{tabular}{|c|c|c|}
\hline Year & Partnerships & Courses \\
\hline 2005 & Rede Globo/Fundação Roberto Marinho & $\begin{array}{l}\text { Technician in Business Administration - } \\
\text { Distance Learning Mode }\end{array}$ \\
\hline 2016 & $\begin{array}{c}\text { UNESCO Representation in Brazil - } \\
\text { United Nations Educational, Scientific and } \\
\text { Cultural Organization }\end{array}$ & $\begin{array}{c}\text { Technician in Administration Integrated to } \\
\text { High School }\end{array}$ \\
\hline \multirow[t]{2}{*}{2017} & $\begin{array}{c}\text { UNESCO Representation in Brazil - } \\
\text { United Nations Educational, Scientific and } \\
\text { Cultural Organization }\end{array}$ & $\begin{array}{c}\text { Technician in Administration Integrated to } \\
\text { High School }\end{array}$ \\
\hline & $\begin{array}{l}\text { Regional Administration Council/São Paulo; } \\
\text { Universidade Metodista de São Paulo }\end{array}$ & Administration technician \\
\hline 2018 & $\begin{array}{c}\text { Regional Administration Council/São Paulo; } \\
\text { Dura Automotive }\end{array}$ & $\begin{array}{l}\text { High School with Professional Qualification } \\
\text { as a Technician in Administration (MTec) }\end{array}$ \\
\hline
\end{tabular}

Source: Prepared by the authors based on Araújo and Demai (2019, p. 93-101).

Regarding these partnerships, it is understood that the performance of the United Nations Educational, Scientific and Cultural Organization (UNESCO) Representation in Brazil and Universidade Metodista de São Paulo is in line with the purposes of these institutions, as well as the participation of the Regional Administration Council, as far as it is responsible for guiding, disciplining, and supervising the Administrator profession. Similar to Rede Globo de Televisão/ Fundação Roberto Marinho, mentioned above, Dura Automotive, headquartered in the United States and with a branch in Rio Grande da Serra, $\mathrm{SP}^{17}$, contributed to creating Etec Rio Grande da Serra. The partnership with CPS, which began in 2018, included the collaboration of the Regional Administration Council for the offer of the High School course with Professional Qualification as a Technician in Administration (MTec), and the Technician in Logistics course, this time in collaboration with the companies Alcis Ltda (logistics software) and Verlog Logística \& Transportes Ltda (see Araújo and Deay, 2019).

When applying for ETEC admission process (known as vestibulinho), students can choose between High School Integrated with Technical Education $(\mathrm{ETIM})^{18}$, High School with Professional Qualification as a Technician in Administration - MTec (NOVOTEC) ${ }^{19}$ and the Project for the Coordination of Secondary and Higher Vocational Training $\left(\mathrm{AMS}^{20}\right)$.

17 Information available at: duraauto.com.br. Accessed on: July 26, 2020.

18 Matrix referenced in the 213 Course Plan, made available by Etec Raposo Tavares. Available at: etecraposotavares.com.br/cursos/etim-administracao/. Accessed on: July 13, 2020.

19 Matrix referenced in Course Plan 427 provided by Etec Prof. Adolpho Arruda Mello. Available at: etecarrudamello.com/cursos-tecnicos. Accessed on: July 16, 2020.

20 It allows students to complete High School, Technical and Technological Higher Education in five years. 
Below, we present a summary chart comparing ETIM and NOVOTEC to indicate the changes introduced with CPS courses being adapted to BNCC and to the secondary education reform, as well as the damages of this educational policy to school content.

Regarding the part that corresponds to technical and professional training, our comparison includes the course with Professional Qualification as a Technician in Administration ${ }^{21}$.

Both the Professional Qualification as a Technician in Administration course, as well as ETIM and NOVOTEC, listed in Chart 4, allow for intermediate training. Although the intermediate certifications and the diploma at the end of the course are equivalent, the courses have subjects with different nomenclatures and workloads.

\section{Chart 4 - Comparative ETIM and NOVOTEC Curriculum Matrices - Common National Core Contents.}

\begin{tabular}{|c|c|c|}
\hline Characteristics & ETIM & NOVOTEC \\
\hline Total number of hours & 3,080 class hours & $\begin{array}{l}2,160 \text { class hours - } \\
\text { the technical workload } \\
\text { is higher }\end{array}$ \\
\hline $\begin{array}{l}\text { Math; Portuguese Language, Literature and } \\
\text { Professional Communication. }\end{array}$ & 480 class hours. & 360 class hours \\
\hline $\begin{array}{l}\text { Modern Foreign Language - English and } \\
\text { Professional Communication. }\end{array}$ & \multicolumn{2}{|c|}{$\begin{array}{l}\text { Workload maintained: } 80 \text { class hours per year } \\
\text { totaling } 240 \text { class hours. }\end{array}$} \\
\hline Spanish (non-mandatory component). & \multicolumn{2}{|c|}{ Workload maintained: 80 class hours. } \\
\hline $\begin{array}{l}\text { Philosophy and Sociology } \\
\text { Both with their workloads reduced to one-third. }\end{array}$ & 120 class hours. & $\begin{array}{l}40 \text { class hours } \\
\text { Philosophy, in the } \\
\text { 2nd grade } \\
\text { Sociology in the 3rd grade }\end{array}$ \\
\hline $\begin{array}{l}\text { Art with reduced class hours, maintained in the } \\
1^{\text {st }} \text { year of high school. }\end{array}$ & 120 class hours. & 80 class hours \\
\hline $\begin{array}{l}\text { Physical education, History, Geography, Physics, } \\
\text { Chemistry, and Biology reduced in one semester, } \\
\text { starting to occur only in the } 1^{\text {st }} \text { and } 2^{\text {nd }} \text { years of } \\
\text { high school. }\end{array}$ & $\begin{array}{l}80 \text { class hours per } \\
\text { year totaling } 240 \\
\text { class hours. }\end{array}$ & $\begin{array}{l}80 \text { class hours only in the } \\
1 \text { st and } 2 \text { nd years totaling } \\
160 \text { class hours. }\end{array}$ \\
\hline \multicolumn{3}{|c|}{$\begin{array}{l}\text { Intermediate training of technical administration by modules: } \\
\text { Module I or 1st year: secondary level technical professional qualification as an administrative assistant. } \\
\text { Modules I + II or 1st + 2nd years: secondary level technical professional qualification as an } \\
\text { administrative assistant. } \\
\text { Modules I + II + III or 1st + 2nd + 3rd years: professional qualification as a technician in administration. }\end{array}$} \\
\hline
\end{tabular}

Source: Prepared by the authors based on selected curriculum matrices.

The bibliographies presented in the teaching plans of ETIM and NOVOTEC courses have the same references for contents of general education and for qualification in administration. This suggests that, although the subjects have different nomenclatures or contents, they have a common work reference.

21 Matrix referenced in Course Plan 421, Etec Parque da Juventude. Available at: etecparquedajuventude.com.br/Cursos/curso.php?curso=5\&u=0\&t=2. Accessed on: July 15, 2020. 
But, when comparing the concomitant and subsequent courses, with regard to the technical professional part, it is noted that there are 15 common references and 20 divergent ones. Of these, nine appear only in the integrated ones, and 11 in the technical administration course, and only 12 authors are cited only in one plan or the other, which provides evidence of a common structuring core in the administration courses, allowing for certifications and diplomas with the same denomination.

Interdisciplinarity is mentioned in all course plans, but it is evident in the NOVOTEC course with a subject named "Integrating Project I and II," 100\% practical workload, offered in the 1 st and 2 nd grades with a total of 160 class hours. This suggests a dialogue between the teachers of the Integrating Project and the Common and Technical Core and between the teachers of the Integrating Project and School Community.

In terms of technical and professional content, the MTec (NOVOTEC) in Administration has a total of 1,440 class hours; of these, almost half, 760 class hours take place in the 3rd grade of high school, compared to what is observed for the contents of the BNCC reduced to 440 class hours, which is equivalent to four/five subjects, namely: "Portuguese Language, Literature and Professional Communication," "Modern Foreign Language - English and Professional Communication," "Mathematics," "Modern Foreign Language - Spanish," when this occurs, and "Sociology," the last two being restricted to the 3rd grade.

Regarding the ETIM in Administration course, 1,320 class hours are reserved for technical and professional content, which are distributed more evenly than in NOVOTEC throughout the high school grades, namely, 400 class hours in the 1st grade; 480 class hours in the 2 nd grade and 440 hours/ class in the 3rd grade.

The Technical Administration course, on the other hand, has a total of 1,500 class hours equally distributed in 500 class hours per course module, which allows us to state that this course has a greater technical and professional workload than the integrated ones that have been investigated. But if we take into account that it includes, as stated in the Teaching Plan, the subject "Language, Work, and Technology," with 40 class hours, focusing on Portuguese Language skills and Professional Communication in the Mother Language, and "Instrumental English," also with 40 class hours, understanding that these two subjects, in the integrated courses, would have some aspects corresponding to the contents worked at BNCC, and therefore could be subtracted from the count, we would have 1,420 class hours of content strictly focused on the technical and professional area. In addition, for the three curricula, there is still a workload of 120 hours reserved for the Course Completion Paper.

When we turn to ETIM and NOVOTEC courses only, it is worth noting that ETIM has a total workload of 4,400 class hours, while NOVOTEC has 3,600 class hours. This represents a difference of 800 class hours of additional studies in integrated teaching and is equivalent to more than half of the workload reserved for the technical and professional part of NOVOTEC, around $37 \%$ of its workload reserved for BNCC contents. 
Although NOVOTEC has a slightly higher workload reserved for technical and professional training, there is a significant loss in terms of the appropriation of knowledge historically constituted by humanity, with an absence of theorists and classics in the bibliography.

By observing the curriculum matrices discussed herein, assuming a curriculum is a political act, it can be said that the reform of high school and BNCC deepen the process of accelerating secondary-level training, its expediting process, and, although certification by competence can enable young people to enter the world of work, it does so in a restricted way, depriving them of their full right to education.

With the decrease in the number of hours in NOVOTEC courses, it is not difficult to realize there is an emptying of educational practices and teaching content. A closer look at the curricular matrices can reveal a drastic process of reducing the knowledge offered to students, since the teaching of instrumental content, apparently more useful to professional skills, is prioritized, reserving more hours to the detriment of teaching general training subjects. This distances students from an integrated and humanistic formation. Although the curricular changes cause losses in both secondary education formats, the flexibility introduced in NOVOTEC creates a new internal segmentation (duality?) in the secondary education offer - a strictly market-oriented format and another more comprehensive format, preparing students for higher education programs.

\section{FINAL CONSIDERATIONS}

Based on the analysis carried out, a double privatization process in and through the professional education policy in the state of São Paulo is found: through an endogenous route, involving the importation of ideas, techniques, and practices from the private sector for formatting the public sector in a similar way as companies and, at the same time, private agents of different kinds increasingly and actively playing a role in policy-making (see Ball and Youdell, 2007; Ball, 2012).

This gives a peculiar characteristic to CPS: the school remains state property but starts to have market-oriented logic and content. The study allows us to state that CPS curricula are shaped in symbiosis with the market demands and, also, in accordance with the current legislation.

In the context of the State Reform and the New Public Administration, the super structures for deepening the advancement of the commercial sector in the public sector are redefined, under the representation of greater civil society participation, and the use of a permanent diagnosis of insufficient coverage by the government to improve the quality of public services.

In this process of civil society homogenization lies the real intentionality of the privilege of spaces for companies and entrepreneurs, in opposition to the active participation of subordinate communities. Therefore, it is worth outlining that antagonistic societal designs exist within civil society, a bad civil society, which develops marketing projects for their own interests of profits above lives, also investing in authoritarian and totalitarian currents (Chambers and Kopstein, 2001). 
With this strategy, the political and ideological dimensions aimed at the impoverishment of the contents taught and the political-pedagogical assumptions of technical-level training were favored through the appropriation of an illusory lexicon of partnerships, entrepreneurship, skills, used to compete for the training offered in public schools, with a business disguise.

In parallel, the most current format adopted for secondary education, $\mathrm{NO}$ VOTEC, integrating BNCC and technical education, proposes short-term professionalization for young people to strictly meet the market's demands for skills. Compared to the format previously implemented, ETIM has reduced workload compared to BNCC.

The growing impoverishment of school curricula, with the removal and emptying of scientific, humanistic, and technological theoretical foundations, which are key for a critical understanding of social reality and active participation in the modern technological society, expresses the political and economic pragmatism of educational reforms imposed by the neoliberal agendas of the federal and state governments.

In this sense, it can be assumed that the project for dismantling secondary and technical education in state and federal schools, as it was possible to verify in CPS, is in line with the absence of socioeconomic demands for the production of science and technology in a country whose economy specializes in creating precarious, low-skilled jobs and/or occupations (with the permanent destruction of production chains and a decline in the participation of the manufacturing industry, especially metal-mechanics, in the gross domestic product - GDP).

In other words, would public technical education privatization, associated with the commodification of education, in these times of financial globalization, be focused on imposing a new subjectivity to students who want to enter the labor market but who are also adapted to unemployment and deprived of their social rights, destined to entrepreneurship, that is, to precarious, subcontracted, and underpaid work? (in addition to a dispute for public funds).

\section{REFERENCES}

ALMEIDA, G. S. B. A.; HERENCIA, J. L. A Fundação Vitae e seu legado para a cultura brasileira - Parte I: fontes conceituais, linhas diretivas, programas próprios e legado. In: SEMINÁRIO INTERNACIONAL DE POLÍTICAS CULTURAIS, 3., 2012, Rio de Janeiro. Anais [...]. Rio de Janeiro: Fundação Casa de Rui Barbosa, 2012. ARAUJO, A. Em 2019, Ensino Médio no Centro Paula Souza terá mais modalidades. Do Portal do Governo, Jan. 03, 2019. Available at: saopaulo.sp.gov.br/spnoticias/ em-2019-ensino-medio-no-centro-paula-souza-tera-mais-modalidades/. Accessed on: Ago 25, 2020.

BALL, S.J. La micropolítica de la escuela: hacia uma teoria de la organización escolar. Buenos Aires: Paidós, 1989.

BALL, S. J. Global Education Inc. New Policy Networks and the Neoliberal Social Imaginary. Didcot: Routledge, 2012. 
BALL, S. J.; YOUDELL, D. Hidden privatisation in public education. Brussels: Education International, 2007.

BALL, S.J.; MAGUIRE, M.; BRAUN, A. Como as escolas fazem as políticas: atuação em escolas secundárias. Ponta Grossa: Editora UEPG, 2016.

BRASIL. Lei Federal n. 5.692/1971, de 11 de agosto de 1971. Fixa Diretrizes e Bases para o ensino de $1^{\circ}$ e $2^{\circ}$ graus, e dá outras providências. Presidência da República, Casa Civil, Subchefia para Assuntos Jurídicos. Brasília, DF: 1971. Available at: http://www. planalto.gov.br/ccivil_03/leis/15692.htm. Accessed on: Dec. 08, 2021.

BRASIL. Constituição da República Federativa do Brasil. Brasília, DF: Senado Federal/Centro Gráfico, 1988.

BRASIL. Lei n. 9.394/1996, de 20 de dezembro de 1996. Estabelece as diretrizes e bases da educação nacional. Brasília, DF, 1996. Available at: http://www.planalto.gov. br/ccivil_03/leis/19394.htm. Accessed on: Dec. 08, 2021.

BRASIL. Decreto Federal n.2.208/1997 de 17 de abril de 1997. Brasilia, DF, 1997. Available at: http://portal.mec.gov.br/seesp/arquivos/pdf/dec2208.pdf. Accessed on: Dec. 08, 2021.

BRASIL. Diretrizes curriculares nacionais para a educação profissional de nível técnico. Brasília: Conselho Nacional de Educação, 1999.

BRASIL. Educação Profissional: referenciais curriculares nacionais da educação. Brasília: Ministério da Educação, 2000. Available at: http://portal.mec.gov.br/setec/ arquivos/pdf/introduc.pdf. Accessed on: Dec. 08, 2021.

BRASIL. Decreto Federal n. 5.154/2004 de 23 de julho de 2004. Presidência da República, Casa Civil, Subchefia para Assuntos Jurídicos. Brasília, DF, 2004. Available at: http://www.planalto.gov.br/ccivil_03/_ato2004-2006/2004/decreto/d5154.htm. Accessed on: Dec. 08, 2021.

BRASIL.Parecer CEB n. 11/2012. Diretrizes Curriculares Nacionais para a Educação Profissional Técnica de Nível Médio. Brasília: Ministério da Educação, 2012a.

BRASIL. Resolução CNE/CEB n. 6/2012, de 20 de setembro de 2012. Define Diretrizes Curriculares Nacionais para a Educação Profissional Técnica de Nível Médio. Ministério da Educação. Conselho Nacional de Educação. Câmara de Educação Básica. Brasília, DF, 2012b. Available at: http://portal.mec.gov.br/index.php?option=com_ docman\&view=download\&alias=11663-rceb006-12-pdf\&category_slug=setembro2012-pdf\&Itemid=30192. Accessed on: Dec. 08, 2021.

CPS - Centro Estadual de Educação Tecnológica Paula Souza. Educação Profissional em São Paulo. São Paulo: CPS, 2000.

CPS - Centro Estadual de Educação Tecnológica Paula Souza. Relatório de Gestão 2004-2008. São Paulo: CPS, 2009.

CPS - Centro Estadual de Educação Tecnológica Paula Souza. Sobre o Centro Paula Souza. Available at: https://www.cps.sp.gov.br/sobre-o-centro-paula-souza/.Accessed on: Jul. 01, 2019.

CHAMBERS, S.; KOPSTEIN, J. Bad civil society. Political Theory, v. 29, n. 6, p. 837-865, Dec. 2001. Available at: https://www.jstor.org/stable/3072607. Accessed on: Dec. 08, 2021. 
COHN, A. O modelo de proteção social no Brasil: qual o espaço da juventude? In: NOVAES, R; VANNUCHI, P. (orgs.). Juventude e sociedade: trabalho, educação, cultura e participação. São Paulo: Perseu Abramo, 2004. p. 160-179.

DEMAI, F.Missão, concepções e práticas do grupo de formulação e análises curriculares (GFAC). In: ARAÚJO, A.; DEMAI, F. (orgs.). Currículo escolar em laboratório: a Educação Profissional e Tecnológica. São Paulo: CPS, 2019. p. 21-130.

FIALA, D. A. S. A política de expansão da Educação Profissional Tecnológica de Graduação Pública no Estado de São Paulo (2000-2007). 2007. Dissertation (Masters in Education) - Universidade Estadual de Campinas, Campinas, 2017.

GUERRA, L. A. F. Construção de currículo no eixo tecnológico de Produção Cultural e Design. In: ARAÚJO, A. M.; DEMAI, F. (orgs.). Currículo escolar em laboratório: a Educação Profissional e Tecnológica. São Paulo: CPS, 2019. p. 288-300.

KORITIAKE, L. A. Reestruturação produtiva e educação: um estudo sobre a proposta do Centro Estadual de Educação Tecnológica Paula Souza para o ensino médio e técnico. 2008. Tesis (PhD in Education) - Universidade Metodista de Piracicaba, Piracicaba, 2008.

LAGANÁ, L. Prefácio. In: ARAÚJO, A. M.; DEMAI, F. (orgs.). Currículo escolar em laboratório: a Educação Profissional e Tecnológica. São Paulo: CPS, 2019. p. 11-12.

LAVAL, C.A Escola não é uma empresa: o neoliberalismo em ataque ao ensino público. Londrina: Plana, 2004.

LIMA, S. H. Educação Profissional e Tecnologia Pública no Estado de São Paulo: um estudo a partir da expansão do Centro Paula Souza. 2020. Dissertation (Masters) - Faculdade Tecnológica, São Paulo, 2020.

MACHADO, L. Organização da Educação Profissional e Tecnológica por eixos tecnológicos. Linhas Críticas, Brasília, v. 16, n. 30, p. 80-108, Jan./Jun. 2010. https:// doi.org/10.26512/lc.v16i30.3571

MAIA, L. C. Z. Mapeamento das escolas técnicas do Centro Paula Souza. Ano 24. Vol. 46. São Paulo: CPS, 2020. Available at: http://www.memorias.cpscetec.com. br/bdcetec/mapeamento/documentos/Unidades2020_1Sem.pdf. Accessed on: Dec. 08, 2021.

MORAES, C. S. V. O que há de novo na educação profissional no Brasil. Trabalho \& Educação, Belo Horizonte, v. 8, p. 13-45, jan./jun. 2001. Available at: https://periodicos. ufmg.br/index.php/trabedu/article/view/9183. Accessed on: Dec. 08, 2021.

MORAES, C. S. V. Educação permanente: direito de cidadania, responsabilidade do Estado. Trabalho, Educação e Saúde, v. 4, n. 2, p. 395-416, Sep. 2006. https://doi. org/10.1590/S1981-77462006000200011

MORAES, C. S. V. O ensino médio e as comparações internacionais: Brasil, Inglaterra e Finlândia. Educação \& Sociedade, Campinas, v. 38, n. 139, p. 405-429, Apr./Jun. 2017. https://doi.org/10.1590/ES0101-73302017177657

MORAES, C. S. V.; ALENCAR, F. Políticas de educação profissional no estado de São Paulo (Relatório de Pesquisa). São Paulo: FAPESP, 2020. 
MORAES, C. S. V.; FERRETTI, C. J. (coords.). Diagnóstico da formação Profissional: ramo metalúrgico. São Paulo: CNM/Unitrabalho, 1999.

OLIVEIRA, J. B. Novos rumos da formação profissional. SEMINÁRIO INTERNACIONAL FIEMG. Anais [...], Belo Horizonte, 1995. Belo Horizonte: FIEMG, 1995.

PERONI, V. M. V. Implicações da relação público-privado para a democratização da educação no Brasil. In: PERONI, V. M. V. (org.). Diálogos sobre as redefinições no papel do Estado e nas fronteiras entre o público e o privado na educação. São Leopoldo: Oikos, 2015. p. 15-34.

PIOLLI, E.; SALA, M. O Novotec e a implementação da Reforma do Ensino Médio na rede estadual paulista. Crítica Educativa, v. 5, n. 1, 2019. https://doi.org/10.22476/ revcted.v5i1.424

QUINTINO, R. M. Classes descentralizadas do Centro Paula Souza na região metropolitana do Vale do Paraíba e litoral norte do estado de São Paulo. 2020. Dissertation (Masters in Gestão e Desenvolvimento da Educação Profissional) Faculdade Tecnológica, São Paulo, 2020.

SACILOTTO, J. V. A educação profissional na agenda de políticas públicas de educação no Estado de São Paulo e a expansão do Centro Estadual de Educação Tecnológica Paula Souza. 2016. Tesis (PhD in Education) - Universidade Estadual de Campinas, Campinas, 2016.

SANTANA, A. C. R. Representações sociais de professores de escolas técnicas estaduais paulistanas sobre a formação técnica integrada ao ensino médio. 2016. Dissertation (Masters in Education) - Universidade Cidade de São Paulo, São Paulo, 2016.

SÃO PAULO (Estado).Lei n. 952/1976, de 30 de janeiro de 1976. Cria a a Universidade Estadual Paulista "Júlio de Mesquita Filho" e dá providências correlatas. Diário Oficial do Estado de São Paulo, São Paulo, Jan. 31, 1976.

SÃO PAULO (Estado). Conselho Estadual de Educação de São Paulo. Processo n. 119/97, de 30 de julho de 1997. Diretrizes para elaboração de Regimento das Escolas no Estado de São Paulo. Diário Oficial do Estado de São Paulo, São Paulo, Ago. 01, 1997.

SÃO PAULO (Estado). Lei complementar n. 1.044, de 13 de maio de 2008. Institui o Plano de Carreiras, de Empregos Públicos e Sistema Retribuitório dos Servidores do Centro de Educação Tecnológica "Paula Souza". Diário Oficial do Estado de São Paulo, São Paulo, 2008.

SÃO PAULO (Estado). Resolução SE n. 18/2019. São Paulo: SEDUC, 2019.

SOUZA, A. N. Professores, modernização e precarização. In: ANTUNES, R. (org.). Riqueza e miséria do trabalho no Brasil II. São Paulo: Boitempo, 2013. p. 217-227. VERGER, A.; NORMAND, R. Nueva gestión pública y educación: elementos teóricos y conceptuales para el estudio de un modelo de reforma educativa global. Educação \& Sociedade Campinas, v. 36, n. 132, p. 573-840, Sep. 2015. http://doi.org/10.1590/ ES0101-73302015152799 


\section{ABOUT THE AUTHORS}

Elydimara Durso dos Reis is a master's student in education from the Universidade de São Paulo (USP).

E-mail: elydimara.reis@usp.br

Carmen Sylvia Vidigal Moraes has a doctorate in sociology from the Universidade de São Paulo (USP). She is a professor at the same institution. E-mail: moraescs@usp.br

Felipe Alencar is a master's student in education from the Universidade de São Paulo (USP). He is also a Pedagogue at the Universidade Federal do $\mathrm{ABC}(\mathrm{UFABC})$. E-mail: felipealencar@usp.br

Conflicts of interest: The authors declare they don't have any commercial or associative interest that represents conflict of interests in relation to the manuscript.

Funding: This research was funded by Coordination for the Improvement of Higher Education Personnel (Conselho Nacional de Desenvolvimento Cientifico e Tecnológico $\mathrm{CNPq}$ ) through the schoolarships offerred to the Master's researcher (Elydimara Reis) and by São Paulo State Research Support Foundation (Fundação de Amparo à Pesquisa do Estado de São Paulo - FAPESP) through the process no. 2018/09983-0 — Educational Policy Research in the São Paulo State Network (Pesquisa Politica Educacional na Rede Estadual Paulista - 1995-2018), which offered the environment to collect data for this study.

Authors' contribution: Project Management, Formal Analysis, Conceptualisation, Data Curation, Writing - First Draft, Writing - Revision and Editing, Research, Methodology: MORAES, C. S. V.; REIS, E. D.; ALENCAR, F. 